\title{
A ética em publicação científica
}

\author{
Ethics in scientific publication
}

Flávio Shansis, Paulo Oscar Teitelbaum*

* Editores, Rev Psiquiatr RS.

Em outubro último, durante o XXVI Congresso Brasileiro de Psiquiatria, realizado na cidade de Brasília, tivemos a oportunidade de participar, na qualidade de editores da Revista de Psiquiatria do Rio Grande do Sul, do Fórum de Publicações em Psiquiatria, cujo tema era "Ciência e Ética em Publicações". A importância do tema, bem como a riqueza da atividade, levou-nos ao desejo de compartilhar com nossos leitores parte do que lá foi discutido, através da seção "Editoriais a convite".

Segundo o dicionário Aurélio, a ética "é o estudo dos juízos de apreciação referentes à conduta humana suscetível de qualificação do ponto de vista do bem e do mal, seja relativamente a determinada sociedade, seja de modo absoluto". Sabemos que a conduta humana é, de forma inevitável, permeada por uma série de interesses, conscientes e inconscientes, alguns dos quais de características eticamente elevadas, visando ao bem comum, enquanto outros - a história da humanidade nos comprova a todo o momento -ceifados do que seria socialmente correto.

Ao analisarmos esse tema no contexto da ciência, observamos o imenso impacto com que tais conflitos éticos podem se refletir sobre a vida de todos nós. A divulgação, no meio científico, de informações e conclusões de pesquisas influencia diretamente condutas clínicas do profissional no atendimento cotidiano de seus pacientes, seja através de modificações técnicas ou de modificações em suas prescrições.
De outra parte, o conflito entre a necessária e desejável divulgação de resultados de pesquisas e a (não menos necessária e desejável) preservação da privacidade e intimidade dos pacientes sujeitos de estudos deve ser igualmente motivo de profunda reflexão e cuidado.

Nesse sentido, as publicações que se ocupam de divulgar material científico devem ter, entre suas maiores preocupações, a busca de mecanismos para a detecção e o manejo de possíveis conflitos éticos envolvendo o que é por elas publicado. Tais mecanismos necessitam estender-se desde a linha editorial, passando pelos membros de seus conselhos editoriais, pareceristas e revisores, culminando com os autores que submetem seus trabalhos para publicação.

Esta é uma preocupação que tem permeado a história da Revista de Psiquiatria do Rio Grande do Sul, através dos colegas que já ocuparam papéis em seu corpo editorial ao longo de quase 30 anos de publicação ininterrupta.

Entretanto, assim como a sociedade muda, em seus conceitos e valores, também precisamos, no contexto de uma publicação científica, estar atentos e disponíveis para discutir conceitos e valores, reavaliar e revalidar nossas posições - porém, mantendo como norte o que é e sempre será indiscutível: a ética, que coloca o valor do respeito humano como marca de toda e qualquer atividade dita científica.

Desejamos a todos uma boa leitura! 